\title{
Mass Media and Evangelization: A View from Japan
}

\section{by José M. de Vera}

It is an acknowledged fact that mass communications, as an academic discipline, is a half-cooked potato. The short time of its existence, the enormous variety of elements that come under its umbrella, the proximity to real life that encourages everybody to talk about it, and many other factors are responsible for this confusing situation. Perhaps the research "Televised Violence and its Behavioral Consequences" is a good illustration of the previous statement. A team of exceptionally competent professionals from several disciplines spent more than two years and several million dollars in a thorough examination of the issues involved. In spite of this exceptional effort when the report was published a bitter dispute broke out among the researchers (some of them claimed that their views have been distorted in the final writing), and the conclusions were far from being clear-cut ${ }^{1}$.

The methodological sophistication of recent research projects have not outdated the famous statement of Berelson in 1940: "Some kinds of communications on some kinds of isues, brought to the attention of some kinds of people under some kinds of conditions have some kinds of effects".

When we come to the field of "Religion and the Media" the problem becomes even more complicated. There are a number of mechanisms that are at work. An obvious one is the "selective mechanism" by which we choose, among all the messages offered by the mass media, the ones which are within our area of interest. Even if religious messages would find their way into the mass media they will be received only by those who have a religious interest. Consequently the ordinary effect of the media is to re-inforce the religious attitudes of the convinced.

A more specific problem has been raised very forcefully by the late Malcolm Muggeridge in his lecture "The Fourth Temptation" 2 . If there had been a fourth temptation when our Lord encountered the Devil in the wilderness this time it would have been an offer of network TV appearances in prime time, to proclaim and expound his Gospel. Jesus, says Muggeridge, would have turned it down all the same, as he had the other three temptations.

Even if he was carried away by the dynamism of the literary metaphor, we can not dismiss lightly Muggeridge's main argument: "an ever-widening chasm between the fantasy in terms of which the media induce us to live, and the reality of our existence as made in the image of God, as sejourners in time whose true habitat is eternity. The fantasy is all-encompassing; awareness of reality requires the seeing eye which comes to those born again in Christ."

The conclusion of Muggeridge is that TV is "beyond redemption" as an instrument to communicate the Faith.

Writing a number of years before, William Kuhns had analyzed, in similar terms, the pervasive "entertainment milieu" which is at the core of TV. "The entertainment milieu", he writes, "has transformed the ways in which we believe and are capable of believing. An absolute kind of belief, as well as belief in absolutes, becomes increasingly difficult as the entertainment milieu trains people to believe tentatively 
and with elasticity. A major Christian tradition, running back as far as St. Paul, has been the insistence that belief in God and the Incarnation of his Son become so total and unmitigated that they constitute metanoia, a transformation of the total person. Belief means complete change, nothing less." 4

Kuhns draws an ambiguous picture of TV and raises very pertinent questions. Even if he does not fall into the electronic despair of Muggeridge, his insistence on the "entertainment milieu" created by TV and its effect on our religious attitudes makes it clear that to uphold such a Christian tradition by the use of the same medium that makes belief so difficult, is next to impossible.

And yet we hear other authoritative voices urging us to use these wonderful instruments of communications in our evangelization tasks. Speaking on "Evangelization in the Modern World" (1975), Paul VI was not excluding TV when he stated that today evangelization cannot dispense with the mass media. "When they are put at the service of the Gospel they are capable of increasing almost indefinitely the area in which the Word of God is heard; they enable the Good News to reach millions of people. The church would feel guilty before the Lord if she did not utilize these powerful means that human skill is daily rendering more perfect. It is through them that she proclaims "from the housetops" the message of which she is depository. In them she finds a modern and effective version of the pulpit. Thanks to them she succeeds in speaking to the multitudes." 5

A look at recent statistics on the "electronic" or "electric church" seems to support the notion of TV as an "effective pulpit". The figure of 130 million Americans who tune in on a religious broadcast (presumably both to radio and TV) in the course of a single week, is impressive. An editorial of "America" (Feb. 24, 1979) notes that "while $42 \%$ of the American people go to church in an average week, $47 \%$ attend an electronic service at home". ${ }^{6}$

The meaning of these statistics, of course, is open to questions. Is the "electronic service at home" a true substitute of the community service? Why do Americans prefer the electronic service? Do healthy Americans use the electronic service as a convenient way of fulfilling an obligation halfheartedly accepted, or out of a genuine desire to share their faith in a communitarian act of worship? Does the "sacred" filter through the 525 lines of the TV sets, or is it a second-class spectacle? Does the electronic service reach the non-Catholics and proclaim to them the Lordship of Jesus Christ, or is the proclamation limited to those who received it already?

On March 8, 1979 the U.S. Catholic Conference sponsored a hearing in Washington to discuss the national communications collection approved by the bishops of the country. One of those who spoke was Fr. Avery Dulles, S. J., professor of theology at the Catholic University of America. Although very supportive of the activities of the church in the field of mass media, Fr. Dulles made a presentation rich in nuances and full of caution. He shares the idea of mass media as a potentially gigantic pulpit from thich the proclamation can be made. But he recognizes that "evangelization, of course, does not consist simply in asserting the lordship of Jesus Christ. It is a complex process by which the believing community seeks to bring the Good News effectively to all strata of humanity ... Public media addressed to a wide audience, evangelization should not be heavy, tedious or abrasive but discreet, interesting and attractive."7 
This is precisely the crux of the problem. Can TV partake in the "complex process" of sharing the Faith? Can a "discreet, interesting and attractive" TV help us to "lift up one's eyes and to see the full dimension of God's call, which beckon us to a transcendent and eschatological salvation?"

The order is a tall one indeed. It brings to one's memory the famous dictum about educational TV in the era before "Sesame street": "if the program is educational it is also dull; if it is interesting it is not educational"... Kuhns and Muggeridge will grab the last words of Fr. Dulles and throw them against the TV monitor.

We could go on pondering all the important questions that the use of TV (and the other media) presents to the Church. Wo could go on to the point of exhaustion or despair. But while the discussion and agony of the experts is an indispensable, most welcome contribution which should not be stopped even if it upsets us, we can not sit down idly waiting for the discussion to finish. There is a clear fact lurking behind all these "yes but": Television is many things. It is useless to try to fix this electronic chameleon as if it were a specimen to be observed under our static microscope. The important thing is to perceive the color and shape of its present stage and draw the pertinent conclusions for its use. Consider the following facts.

For a number of years we have been saying that TV is the "chewing gum of the eyes"; that it is one more piece of furniture; that while watching TV our brains produce the same type of waves as when we are about to fall asleep; that it is like the air: we feel its need only when it is not available ... In spite of all these assertions, at this writing there is an American TV series that has created a sensation around the world. Businessmen away in foreign countries call long distance to know what happened in the last installment of "Dallas"; State Ministers in South Africa refuse speaking engagements the nights on which the Program is broadcast because the audience will be minimal; the traffic in London is light if "Dallas" is on the air ... We knew that back in 1950 people will rush home to watch some programs. But we never believed that it will happen in 1980.

In the religious field we have written off the possibility of a second Fulton Sheen's performance with the famous converts who were motivated by a man in ecclesiastical robes speaking in front of a blackboard. But are we sure that a charismatic presence is all together an impossibility? Even the reluctant Muggeridge speaks of the tremendous effect of a TV interview he made to Mother Theresa before she became known all over the world.

Again: TV is many things. Its effectiveness and impact is shaped by the social, cultural, spiritual and economic situation of a given country at a given moment. Whether the novelty has worn off; whether there is a channel or 50 channels available; whether the history of TV in the country is long or short; whether the institutional Church is vigorous or declining. All and each one of these factors will be vital in the effectiveness of TV as a "pulpit" to proclaim the Christian message and help the people "to lift up their eyes and see the full dimensions of God's call" 8 .

In summary: because under certain circumstances mass media can not perform all the tasks that the Church has to carry out in order to fulfill her mission, it does not mean, as Muggeridge stated, that it can not do any of the tasks connected with evangelization. Humility, realism and professionalism will dictate the concrete use of the media at a given time. 
The preceeding reflexions lead us to examine, briefly, the function of mass media for evangelization in Japan on the basis of the data obtained from "The Image of Christianity in Japan", a survey conducted in $1977^{9}$.

Japan's population is around 114 million, of which less than one million are christians. (Catholic: 437,066 Protestant: 710,619) In spite of being such a "minor minority", the survey reveals two basic facts about Christianity in Japan.

1) The knowledge of Christianity is widely spread.

When the survey asked the respondents to list all the established religions they could recall, $79 \%$ in the metropolitan area and $76 \%$ in the non-metropolitan area, listed Christianity. Corresponding figures for Buddhism were $82 \%$ and $85 \%$. When aided to identify the names of major religions by showing printed-cards, $99 \%$ identified Christianity and Buddhism as world religions. Compared with Christianity and Buddhism other religions were recalled much less frequently. (Soka Gakkai was mentioned by $26 \%$ of the respondents in the metropolitan area and $39 \%$ in the nonmetropolitan area).

Even more significant, perhaps, is the fact that $76 \%$ in the metropolitan area gave the name of Jesus Christ as the Founder of Christianity while only $59 \%$ could name the Founder of Buddhism. (The percentages in the non-metropolitan area were 75 for Christianity an 49 for Buddhism.)

Leaving aside the historical facts, $9 \%$ of the Japanese thought that "love" was the focal point of Christianity; $39 \%$ recognized Christ as an ideal man; $18 \%$ as a historical person; $10 \%$ as a messenger of God.

These statistics, ov course, are open to diverse interpretations but they undoubtedly show a high level of knowledge about Christianity among the population at large.

\section{2) Christianity has won social acceptance.}

A list of 17 adjectives were shown to the respondents who were asked to choose any of them which they thought applicable to each religion. The composite result shows that the respondents perceived Christianity as "bright, rather refined, quite strict, modern, free from pietism, active, not pretentious and somewhat foreign. Further, it is "somewhat arbitrary, close to common people, friendly, intellectual, not wealthy, ethical, not overly emotional, yet quite hypocritical".

The image of Buddhism is "gloomy, not very refined, very strict, old fashioned, pietistic, not very active, and emotional". But Buddhism is "free from being foreign, not ostentatious, very close to common people, not very hypocritical, friendly, very ethical, not intellectual, not wealthy, warm in feeling and quite emotional."

The translation of the adjectives into English is difficult and the linguistic idiosyncrasy may leave some doubts about important nuances. Also, we must realize that the Japanese are talking of Christianity as they have experienced it in their evironment, and in comparison with other religions. Even with these reservations there is no doubt that the image of Christianity among the Japanese is a positive one. The "foreign flavor" of Christianity, one of the potential obstacles or negative elements, is mentioned only by $10 \%$ of the respondents. 
If we recall that less than $1 \%$ of the Japanese are Christians (embracing both Catholic and Protestants), we may wonder how this knowledge of Christianity, and this favorable image have come into existence. In other words: how and where have the Japanese come in contact with the Church.

The survey shows that one out of seven Japanese has attended a Christian school. The highest percentage belongs to the High School followed by Universities and Kindergarten. In the metropolitan are $29 \%$, and in the non-metropolitan area $36 \%$ have attended "mission schools".

The second source of knowledge about Christianity, as mentioned by the respondents, is "mass media": $17 \%$ in the metropolitan and $13 \%$ in the non-metropolitan. Within the mass media the printed word occupies the first rank ( $10 \%$ in the metropolitan, $2 \%$ in the non-metropolitans sample). Radio and TV come second ( $4 \%$ and $6 \%$ respectively). Finally, movies and theatrical plays are mentioned. (3\% and $5 \%$ )

A word of caution seems to be in order regarding the mass media. It should not be interpreted, in any way, as if the "proselitizing use" of the media had produced such results. Although the survey did not explore this particular aspect it is beyond doubt that a great good deal of information regarding Christianity was received from the secular mass media. Films like "Sound of Music", radio programs of Gregorian chant broadcast with detailed explanations about the words and its meaning, etc, have had this cumulative effect. Difficult to measure but undeniably real is the influence of recognized Christian novelists. Nobody has ventured a satisfactory hypothesis to explain this phenomenon, but the number of first-rate novelists among Japanese Christians is well beyond expectation. These authors have dealt, quite often and openly, with Christian topics: from a book on Jesus (best-seller) to novels where priests are protagonist or basic Christian tenets are discussed in literary form. The names of these Christian writers are seen routinely in the list of bestseller's authors. This anomalous situation of a minor-minority producing a large and disproportionate number of first-class writers who deal with problems related to their Christian Faith must have had a real impact on the population at large even if, so far, we have not measured it.

Before we draw specific conclusions it seems that an overall view of the media in Japan and its relationship with the Church is in order.

In the printed media the dissemination of books about Christianity (both in Japanese and in translation) is broad and solid. Several monthly magazines and a bimonthly Catholic Newspaper complement the Work of the Catholic publishers. Avid readers as the Japanese are, this activity represents a magnificent contribution to the Christian education in Japan. On the other hand the gigantic secular press is beyond the reach of the Church. A Christian writer may be invited to write a novel in installments. (The national newspapers in Japan carry serial novels. Sono Ayako, a prominent Catholic novelist, has been one of those writers). An interview with a Christian educator may be appeared. An article on Christian art may be commissioned. Exceptionally important news (the death of a Pope, the election of a new one) will find its way into the press. (The visits of the Pope to Brasil and Africa were not even mentioned in the big Japanese newspapers). Unusual news (a Catholic priest who has opened a bar in a popular section of Tokyo) will be also reported. But the presence of the Church in the press is sporadic and always at the initiative of the 
editors. There is no room for theological considerations. Religion appears only occasionally and on the strength of news value.

Television broadcasting is also a forbidden field to the Church. No station or network will sell time to a religious institution for proselitizing programs on a continuous way. Only two stations in Tokyo broadcast "religions programs", one of them is a private channel (NTV) which has a 15 minutes broadcast on Sundays at 6:30 a.m. The other is an educational channel of NHK (the giant public broadcasting company) which devotes one hour every Sunday morning (repeated in the afternoon). Four or five times a year a Christian will be invited to appear in the program which is produced by the NHK staff and it is limited to a "talk show" with visual illustration. Sometimes representatives of different religions participate in round-table discussions. Proselitizing and devotional programs are not allowed. Several years ago a group of Christian broadcasters approached the NHK with two proposals: to offer the religious program at a better time (it was broadcast then only at 6:00 a.m.), and to allow the different denominations to produce their own programs. Only the first proposal was accepted.

Apart from the religious program mentioned above, NTV is broadcasting twice a week a Program ("Light of the Heart") in cooperation with a Catholic Organization. The decision power is with NTV but there is a close cooperation with the Catholic group which pays a very reasonable amount of money for the production and the airtime. The content, however, is not strictly religious. Only occasionally a direct Christian topic is taken up although often a priest appears in the Program wearing the Roman collar. The duration is 15 minutes and the format, for the most part, is "interview".

Finally, there is a Protestant program on a local UHF station.

Radio broadcasts are more open to religious influence. It is possible to buy time in local stations. At present there are two Catholic programs on the air, one in 35 stations and the other in 24 . Both are short ( 5 minutes) and broadcast at convenient time for radio audiences. In short-wave, Radio Veritas (from the Philippines) and Vatican Radio have limited but faithful audiences.

Going back to the Survey, the data obtained emphasize a problem that has been confronting the Church in Japan for a number of years, and that puzzles many of us. We have verified a wide-spread knowledge of Christianity that, even if it can not be qualified as deep, certainly goes beyond a mere recognition of the name. On top of that, the perception of Christianity by the population at large is positive as the composite image of the survey shows. Moreover, a surprising number of Japanese come in contact with the Church in a way or another. Finally, an independent survey, prior to the one we undertook, shows that if forced to choose a Religion, the majority of white-collar workers will choose Christianity. In spite of the above data the number of committed (baptized) Christians is small and stagnant: 437,066 Roman Catholics and 710.619 Protestants (all denominations included). This is the puzzle. We are not going to try to unravel it. Our considerations will be reduced to explore the role that the media can play in this given situation.

From a pure sociological point of view, the situation of the Church in Japan is one in which mass media are least effective. Researchers have pointed out, time and again, that the media can be very effective for the "awareness" stage and the "building" of 
images. They also have stressed the weakness of the media when "change" or "conversion" (even non-theological conversion) is concerned. But it is precisely "change", "conversion", "commitment", "decision" what is missing among the Japanese regarding Christianity. Consequently, if we would hire mass-media consultants to advise the Church leaders in the use of the media to solve the impasse, there is little doubt about their recommendations: to provoke this personal surrender to Christ (the crucial point in our Japanese situation) the mass media do not hold great promise. One would be tempted to say that the media have made its basic contribution to the evangelization of Japan: dissemination of information and building of a positive image. These goals have been accomplished not exclusively but certainly with the contribution of the media.

If the Church were completely free in deciding the use of mass media in Japan (especially TV) one could think of "direct" and "regular" programs which would try to shake the Japanese in their religious complacence; which would emphasize the need for commitment. But neither the cultural atmosphere nor the broadcasting practices of the country allow it. Consequently, the contribution of the media to the concrete needs of evangelization in Japan seems to be in the "group media" rather than in the futile attempt to emphasize "mass media". The group media present the Christian message in the audio-visual language that is effective in our contemporary society. On the other hand, this audio-visual language is handled by a group-leader (a catechist) who can share, communicate, his faith and his commitment.

The "Survey on the Image of Christianity in Japan" shows that although the real number of Christians is less than $1 \%$ of the population, $2 \%$ of the Japanese consider themselves Christian. Moreover, the survey also has found that $22 \%$ of the Japanese can be classified als "prone to religiosity". These people in the periphery of Christianity could be helped to make a personal commitment, if properly approached. There lies, perhaps, the hope and the challenge of the Church in Japan. The group media, combining a contemporary language and a person-to-person situation, could be the right tool at the right moment.

\section{Footnotes}

1 Television and Social Behaviour. A Technical Report to the Surgeon General's Scientific Advisory Committee on Television and Social Behaviour. U.S. Department of Health, Education and Welfare. Washington 1972. Five Volumes.

2 Malcolm Muggeridge: Christ and the Media, William Eerdmans Publishing Company, Hodder and Stoughton, Sevenoaks, Kent England, 1977.

3 Ibid. Page 30.

4 William Kuhns: The Electronic Gospel. Religion and Media. Herder and Herder, 1969, p. 165.

5 Paul VI: On Evangelization in the Modern World, (1975), N. 45.

6 "America”, Feb. 24, 1979, p. 122.

07 Avery Dulles, sj: Mass Evangelization Through Social Media, Catholic Mind, Juni 1980, p. 45.

8 Paul VI: On Evangelization in the Modern World, N. 26.

9 The Image of Christianity in Japan. A Survey. English Version Edited by James P. Colligan. Institute of Thristian Culture, Sophia University, Tokyo, 1980. 
Massenkommunikation ist als akademische Disziplin durchaus noch nicht allgemein anerkannt. Noch viel schwieriger ist dies im Bereich „Religion und Medien“. Hier wirken offensichtlich eine Reihe von besonderen Mechanismen; einer davon ist z.B. der Auswahlmechanismus: wir wählen das, was uns gefällt. So werden religiöse Botschaften innerhalb der Massenmedien nur von jenen aufgenommen, die religiös interessiert sind. Das Ergebnis ist also eine Bestärkung vorhandener Einstellungen. Malcolm Muggeridge hat „Die vierte Versuchung" als ein besonderes Problem behandelt: die vierte Versuchung Jesu bestand in des Teufels Offerte zur Benutzung aller Fernsehnetze, zur Verbreitung des Evangeliums in der besten Sendezeit. Nach Muggeridge hätte Jesus auch diese Offerte abgelehnt und seine Begründung dafür: die Diskrepanz zwischen der Scheinwelt der Medien und der Wirklichkeit unseres Lebens als Geschöpfen nach dem Bilde Gottes. Muggeridge folgert, daß das Fernsehen als Instrument der Kommunikation des Glaubens jenseits aller Erlösungsfähigkeit sei. Vor ihm hatte Kuhn in ähnlicher Weise darauf verwiesen, daß das Fernsehen als Unterhaltungsinstrument nicht zur Veränderung der ganzen menschlichen Person im Sinne christlichen Glaubens führen kann. Aber es gibt auch andere Stimmen. So hat Papst Paul VI. in seinen Ausführungen über Evangelisation in der modernen Welt (1975) das Fernsehen nicht ausgeklammert, als er u.a. sagte, die „Kirche würde vor ihrem Herrn schuldig, wenn sie nicht diese machtvollen Mittel nützte, die der menschliche Verstand immer noch weiter vervollkommnet" (No. 45). Ein Blick auf die neuesten Statistiken der „elektronischen Kirche" scheint das Fernsehen als fruchtbare Kanzel zu bestätigen. Immerhin schalten 130 Millionen Amerikaner jede Woche wenigstens einmal religiöse Programme ein: während $42 \%$ der Amerikaner wöchentlich zur Kirche gehen, sehen $47 \%$ die Gottesdienste am Fernsehen. Natürlich sind solche Zahlen offen für jede mögliche Interpretation... In einem Hearing vor der US Catholic Conference am 8. März 1979 hat Avery Dulles u.a. darauf hingewiesen, daß Evangelisation nicht nur allein in der Bezeugung von Jesus Christus als dem Herrn bestehe. Es ist vielmehr ein vielfältiger Vorgang, bei dem die gläubige Gemeinde versucht, die gute Nachricht wirkungsvoll in alle Bereiche menschlichen Lebens zu bringen.

Dies ist aber genau der Kern der Schwierigkeit. Kann das Fernsehen an diesem „vielfältigen Vorgang" teilnehmen? .. Man könnte fortfahren, theoretisch zu diskutieren, aber man muß auch die gegenwärtigen Fakten sehen. Gerade hat ein amerikanischer Sender eine Sensation um die ganze Welt geschaffen. Geschäftsleute telefonieren vom Ausland, um die Ereignisse der letzten „Dallas“-Sendung zu erfahren. Und das im Jahre 1980! Im Bereich religiöser Programme haben wir die Möglichkeit eines zweiten Fulton Sheen abgeschrieben. Aber sind wir sicher, daß eine neue charismatische Gegenwart wirklich unmöglich ist? Auch der zögernde Muggeridge spricht von der hervorragenden Wirkung eines Fernsehinterviews mit Mutter Teresa, und das, bevor sie allgemein bekannt wurde. Wenn die Massenmedien unter bestimmten Umständen nicht alle Aufgaben der Kirche erfüllen, heißt dies nicht, daß sie dazu nicht doch beitragen könnten. Auf diesem Hintergrund seien die folgenden Informationen gegeben, die auf einer Untersuchung aus dem Jahre 1977 über „das Image des Christentums in Japan" beruhen. Obwohl die Christen nicht einmal eine Million unter insgesamt 114 Millionen Japanern ausmachen, brachte die Untersuchung zwei wichtige Erkenntnisse:

1. Die Kenntnis des Christentums ist weit verbreitet. $79 \%$ der Befragten in der Stadt und $76 \%$ auf dem Lande nannten das Christentum eine der anerkannten Religionen; die entsprechenden Zahlen für den Buddhismus lagen bei $82 \%$, bzw. $85 \% .99 \%$ der Befragten bezeichneten Christentum und Buddhismus als Weltreligionen.

2. Das Christentum ist gesellschaftlich angenommen. Anhand vorgegebener Eigenschaftswörter bezeichneten die Befragten das Christentum u.a. als hell, klar umschrieben, genau, modern, frei von Frömmlertum, aktiv, nicht tendenziös, aber etwas fremdländisch, während der Buddhismus u.a. als unklar, nicht sehr genau, sehr streng, altmodisch frömmlerisch, nicht 
sehr aktiv und gefühlsbestimmt, aber nicht fremdländisch bezeichnet wurde. Allerdings ist die Übersetzung solcher Ausdrücke aus dem Japanischen nicht ganz einfach. Jedenfalls sprechen die Japaner vom Christentum, wie sie es in ihrer eigenen Umgebung im Vergleich mit anderen Religionen kennengelernt haben. Es besteht kein Zweifel, da B für sie das Christentum eine positive Erscheinung ist. Wenn man jetzt wieder bedenkt, daB die Christen noch nicht einmal $1 \%$ der Bevölkerung darstellen, muß man doch fragen, woher der Durchschnittsjapaner dieses positive Bild des Christentums hat. Wo und wann hat er das Christentum kennengelernt? Die Untersuchung zeigt, daß einer von 7 Japanern eine christliche Schule besucht hat, dann aber folgen schon als zweite Quelle der Kenntnis des Christentums die Massenmedien. $17 \%$ der Stadtbewohner und $13 \%$ der Landbevölkerung kennen das Christentum durch die Massenmedien. Dabei steht das gedruckte Wort an erster Stelle, gefolgt von Hörfunk und Fernsehen, aber auch von Film und Theater. Dabei muß man allerdings wohl bedenken, daß dieser Einfluß nicht von „Bekehrungsversuchen“ dieser Medien herkommt. Zwar ist die Untersuchung hier nicht in Einzelheiten gegangen, aber es steht außer Zweifel, daß diese Entwicklung christlichen Filmen, Theaterstücken und vor allem auch christlichen Schriftstellern zu verdanken ist, denn überdurchschnittlich viele der bedeutendsten Schriftsteller Japans sind praktizierende Christen.

Daraus ergibt sich seit Jahren ein Problem für die Kirche: Die Kenntnis des Christentums ist weit verbreitet, ist zwar nicht tief, geht aber über die reine Kenntnis des Namens hinaus. Ferner ist das Image des Christentums positiv, und eine überraschend große Zahl von Japanern kommt in der einen oder anderen Weise mit der Kirche in Kontakt. Dabei bleibt jedoch die Zahl der wirklichen Kirchenmitglieder klein und konstant (437.066 Katholiken, 710.619 Protestanten). Die Situation der Kirche in Japan ist so, daß sie keine Bekehrungen hat, etwas, das die Medien nicht bringen können, die wohl wirkungsvoll sind, um Bewußtsein zu bilden und Kenntnis zu erzeugen. Fast möchte man sagen, daß die Massenmedien in Japan hier ihren Teil für das Christentum geleistet haben. Man könnte sich darüber hinaus höchstens noch direkte und regelmäßige Bekehrungsprogramme im Funk vorstellen, die aber weder rechtlich möglich noch vom kulturellen Umfeld her empfehlenswert sind. Wohl aber hätten hier noch die sogenannten Gruppenmedien eine Aufgabe; durch den Gruppenleiter und audiovisuelle Mittel im kleinen Kreis jene Menschen, die dem Christentum nahestehen, zu einer Entscheidung zu helfen.

\section{RÉSUMÉ}

Muggeridge, tout comme Kuhn, ne considèrent pas les mass media, tels que la télévision, comme propres à amener une conversion dans le sens de la foi chrétienne. Paul VI encouragea cependant à se servir de ce moyen. L'auteur essaie de faire des recherches à ce sujet, à l'aide d'une enquête de 1977 sur l'idéal de la chrétienté au Japon. Bien que les chrétiens, catholiques et protestants ensemble, ne comptent même pas un million parmi les 114 millions de Japonais, le résultat de l'enquête montra que la chrétienté au Japon, en tant que religion reconnue, atteint presque la même pourcentage que le bouddhisme. De plus, la chrétienté est socialement accepté et est même décrite plus positivement que le bouddhisme. Ainsi l'enquête montra que ce sont d'abord les écoles chrétiennes, puis les mass media qui en sont responsables. Le mot imprimé - d'importants écrivains du Japon sont des chrétiens pratiquants occupe la première place. Mais ensuite suivent la radio et la télévision, le film et le théatre. Ainsi, l'auteur pense qu'il est possible que les soi-disants medias de groupe aient ici, surtout les moyens audio-visuels, une importante fonction complémentaire afin de faire progresser la chrétienté au Japon. 


\section{RESUMEN}

Tanto Muggeridge como Kuhn no consideran los medios de comunicación, la televisión por ejemplo, como adecuados para favorecer una conversión en el sentido de la fé cristiana. Pablo VI preconizó, sin embargo, la utilización de estos medios. El autor trata de seguir la pista a esta problemática partiendo de un estudio de 1977 sobre la imagen del Christianismo en Japón. A pesar de que los cristianos de Japon, sumando católicos y protestantes, no llegan al millón entre una población de 114 millones de habitantes, el resultado del estudio muestra que el Christianismo alcanza como religión en Japón un grado de reconocimiento casi tan grande como el Budismo. Según el estudio, esta realidad es fruto en gran parte de las escuelas cristianas, pero también de los medios de comunicación social y de la palabra impresa en primer lugar: importantes escritores de Japón son cristianos practicantes. Siguen en influencia la radio, la televisión, el cine y el teatro. El autor opina que, con grupo, sobre todo los medios audiovisuales, podrian jugar una importante misión complementaria. 